\title{
5.6. ГОСУДАРСТВЕННАЯ ФИНАНСОВАЯ ПОДДЕРЖКА РАЗВИТИЯ СЕЛЬСКОГО ХОЗЯЙСТВА: ОЦЕНКА РАСХОДОВ И ПРОБЛЕМЫ
}

\author{
Сергиенко Н.С., доцент кафедры
}

«Государственное и муниципальное управление»

\author{
ФГОБУ ВО «Финансовый университет при Правительстве РФ», г. Москва
}

В научной статье рассматривается сформировавшийся опыт государственной финансовой поддержки, направленной на развитие сельского хозяйства. В работе на основе оценки расходов федерального бюджета на сельское хозяйство рассмотрены проблемы финансового обеспечения мер поддержки развития агропромышленного комплекса и полноты использования выделенных бюджетных ресурсов.

\section{Литература}

1. Прогноз инфляции [Электронный ресурс] // Прогноз долгосрочного социально-экономического развития РФ на период до 2030 г. : разработан М-вом экон. развития РФ. Доступ из справ.-правовой системы «Консультант Плюс».

2. Антонова Д.Ю. Государственная поддержка сельского хозяйства в условиях членства Российской Федерации во Всемирной торговой организации [Текст] / Д.Ю. Антонова, Д.С. Козлов // Сельское хозяйство. - 2018. - №4. - С. 3.

3. Балынин И.В. Комплекс предложений по повышению прозрачности общественных финансов в Российской Федерации [Текст] / И.В. Балынин // Аудит и финансовый анализ. - 2018. - №4. - С. 80-84.

4. Балынин И.В. Предварительные итоги финансового обеспечения сельского хозяйства и рыболовства в российской федерации в 2016 году [Текст] / И.В. Балынин // Глобальные проблемы модернизации национальной экономики : матлы VI Междунар. науч.-практ. конф. (очно-заочной) : в 2 ч. - 2017. - С. 38-45.

5. Бюллетень Счетной палаты РФ [Электронный ресурс]. - 2015. - №12 // Счетная палата PФ : официальный сайт. - URL : http://www.audit.gov.ru/activities/bulleten/?section= $822 \# 867$.

6. Бюллетень Счетной палаты РФ [Электронный ресурс]. - 2016. - №1 // Счетная палата РФ : официальный сайт. - URL : http://www.audit.gov.ru/activities/bulleten/?section= $868 \# 869$.

7. Бюллетень Счетной палаты PФ [Электронный ресурс]. - 2017. - №4 // Официальный сайт Счетной палаты PФ URL: http://www.audit.gov.ru/activities/bulleten/?section= 888\#893 (дата обращения: 01.12.2019).

8. Бюллетень Счетной палаты РФ [Электронный ресурс]. - 2019. - №1 // Счетная палата РФ : официальный сайт. - URL : http://www.audit.gov.ru/activities/bulleten/?section= 936\#937.

9. Бюллетень Счетной палаты РФ. - 2014. - №2 [Электронный ресурс] // Счетная палата РФ : официальный сайт. - URL : http://www.audit.gov.ru/activities/bulleten/?section=559\#654.

10. Горбатов А.В. Состояние и развитие экспорта сельскохозяйственной продукции и продовольствия в России [Текст] / А.В. Горбатов // Управление экономическими системами. - 2016. - №11. - С. 10.

11. Государственная поддержка сельского хозяйства: развитые и развивающиеся страны [Текст]. - М. : М-во сельского хва РФ ; Департамент агропромышленной политики, 2017. - С. 4.

12. Казначейство России [Электронный ресурс]. - URL : http://www.roskazna.ru/ispolnenie-byudzhetov/federalnyj-byudzhet/.

13. Матвеева Е.Е. Обеспечение уровня экономической безопасности региона [Текст] / Е.Е. Матвеева, Ю.В. Гнездова // Бизнес. Образование. Право. - 2019. - №1. - С. 64-69.

14. Организация консультационной деятельности в агропромышленном комплексе [Текст] : учеб. и практикум для бакалавриата и магистратуры / В.М. Кошелев [и др.] ; под ред. В.М. Кошелева. - М. : Юрайт, 2019. - С. 256.

15. Пинская М.Р. Налоговые меры государственной поддержки экономического роста в сельском хозяйстве [Текст] / М.Р. Пинская // Налоги и финансы. - 2016. - №1. - С. 29.

16. Прокофьев М.Н. Оценка проблем государственной финансовой поддержки сельского хозяйства в Российской Федерации [Текст] / М.Н. Прокофьев, А.С. Сибиряев // Вестн. НГИЭИ. - 2017. - №7. - С. 110-116.

17. Прокофьев С.Е. Кассовое обслуживание федерального бюджета: итоги и перспективы [Текст] / С.Е. Прокофьев // Финансы. - 2012. - №6. - C. 24-27.

18. Прокофьев С.Е. Расходно-операционный блок Казначейства России: итоги и перспективы [Текст] / С.Е. Прокофьев // Финансы. - 2016. - №4. - С. 29-35.

19. Ушачев И. и др. Актуальные направления совершенствования аграрной политики России [Текст] / И. Ушачев, А. Серков, В. Маслова, В. Чекалин // АПК: экономика, управление. - 2019. - №3. - С. 8.

20. Шаурина О.С. Повышение качества продуктов питания отечественного производства как составляющая продовольственной безопасности России и ее регионов [Электронный ресурс] / О.С. Шаурина, А.В. Горбатов // Политематический сетевой электрон. науч. ж-л Кубанского гос. аграрного ун-та. - 2016. - №119. - С. 1064-1076.

\section{Ключевые слова}

Сельское хозяйство; государственная поддержка; бюджет; расходы бюджета; агрострахование; кассовое исполнение.

\section{Сергиенко Наталья Сергеевна}




\section{РЕЦЕНЗИЯ}

В научной статье содержатся результаты исследования реализации государственной политики по поддержке развития сельского хозяйства в Российской Федерации посредством различных финансовых инструментов.

Актуальность представленной статьи не вызывает сомнений, так как на современном этапе анализ бюджетных расходов на поддержку сельского хозяйства в условиях проводимой политики импортозамещения позволяет оценить ярко выраженный проблемный характер освоения бюджетных ресурсов в данной отрасли.

Автор в научной статье представил результаты исследования применяемых механизмов поддержки и полноты использования выделенных бюджетных ресурсов.

Научная новизна и теоретическая значимость научного исследования обусловлены комплексным подходом к оценке реализации государственной финансовой политики по поддержке развития сельского хозяйства.

В работе обозначены проблемы эффективного использования бюджетных ресурсов, направляемых на развитие сельского хозяйства, в том числе на основе материалов контрольного ведомства

Практическая значимость результатов исследования заключается в возможности их использования для принятия конкретных управленческих решений по вопросам финансового обеспечения развития агропромышленного комплекса в целом.

В качестве замечания можно отметить недостаточное внимание в статье проблемам внедрения программно-целевого подхода при поддержке указанной отрасли, что не снижает качества исследования в целом.

Научная статья «Государственная финансовая поддержка развития сельского хозяйства: оценка расходов и проблемы» Н.С. Сергиенко актуальна, полностью отвечает существующим требованиям, которые предъявляются к подобным научным трудам. Статья может быть рекомендована к публикации в специализированном журнале.

Скоробогатова Т.Н., д.э.н., профессор кафедры государственного и муниципального управления ФГАОУ ВО «Крымский феедеральный университет им. В.И. Вернадского», г. Симферополь

DOI 10.38097/AFA.2020.43.35.015 